\title{
Societies Without Borders
}

Volume 4 | Issue 3

Article 1

2009

\section{W.E.B. Du Bois, Race, and Human Rights}

Elias

Follow this and additional works at: https://scholarlycommons.law.case.edu/swb

Part of the Human Rights Law Commons, and the Social and Behavioral Sciences Commons

\section{Recommended Citation}

Elias. 2009. "W.E.B. Du Bois, Race, and Human Rights." Societies Without Borders 4 (3): 273-294.

Available at: https://scholarlycommons.law.case.edu/swb/vol4/iss3/1

This Article is brought to you for free and open access by the Cross Disciplinary Publications at Case Western Reserve University School of Law Scholarly Commons. It has been accepted for inclusion in Societies Without Borders by an authorized administrator of Case Western Reserve University School of Law Scholarly Commons. 


\title{
W.E.B. Du Bois, Race, and Human Rights
}

\author{
Sean Elias \\ Southern Methodist University
}

\begin{abstract}
Du Bois' sociological thought reveals an overlooked tension in the pursuit of human rights, a tension between universal human rights for all people, in general, and a race-specific human rights agenda for blacks, in particular. Du Bois recognizes both universal human rights for all individuals, groups, nations, and international bodies (regardless of race, gender, class, and other human divisions) and case-specific human rights for particular individuals, groups, nations, and international bodies (with regard to race, gender, class, and other human divisions). I aim to demonstrate why Du Bois' acknowledgment of universal and case-specific human rights, and dynamics of their interrelationship, improves contemporary sociological thought about the complexities of addressing human rights issues and provides a more nuanced model for human rights social action.
\end{abstract}

\section{Keywords}

human rights, race, Du Bois, oppression

[T]he national and Race ideal has been set before the world in a new light - not as meaning subtraction but addition, not as division but as multiplication - not to narrow humanity to petty selfish ends, but to point out a practical open road to the realization in all the earth of a humanity broad as God's blue heavens and deep as the deepest human heart.

W.E.B. Du Bois, 1900[?] ${ }^{1}$

\section{Introduction}

Undoubtedly, W.E.B. Du Bois is one of the great sociologists of human rights and still stands as an exemplary model for human rights activists and public sociologists worldwide. Du Bois was among the select few of

1) Du Bois 1985a.

(๔) Koninklijke Brill NV, Leiden, 2009

DOI: $10.1163 / 187188609 X 12492771031492$ 
early social reform, social justice-seeking public sociologists who initiated a moral sociological approach to investigating and solving pressing human rights issues facing the social world during rapid, widespread changes of the late nineteenth and early twentieth centuries. He, along with other early pioneering public sociologists, such as Harriet Martineau, Karl Marx, W.I. Thomas, Jane Adams and other Hull House women sociologists, acknowledged social problems and human suffering caused by dysfunctional social systems and exploitative groups that prey on the disempowered and nonaggressive. $^{2}$

Public oriented, morally grounded sociology concerned with human rights issues was a short-lived movement in the formation of the discipline, as the early generation of public sociologists were quickly eclipsed and de-legitimized by a new generation of early twentieth century sociologists who moved away from sociology concerned with social reform, social justice, and human rights. ${ }^{3}$ Guided by private interests and government policy formation that, in practice, challenged the welfare of oppressed and marginalized groups, this new generation of sociologists developed and promoted a detached, objective sociological approach that avoided moral questions and the political pursuit of human rights. ${ }^{4}$

Being a younger member of the first-generation public sociologists concerned with human rights development, and blessed with a long, healthy life, Du Bois continually opposed the moral ambivalence and bias-cloaked objectivity in institutionalized - mainstream - sociology, continuing the challenging work of public sociology into the second half of the twentieth century. Despite intellectual opposition and social marginalization, he persevered as a sociologist of human rights and kept public sociology afloat, even as the moral and human rights concerns of public sociology were rapidly replaced by the "objective," policy-driven professional concerns of mainstream "scientific" sociology that largely defines the discipline to this day. ${ }^{5}$

Developing a clear theoretical picture of Du Bois' understanding of human rights is tricky, considering that he presents several conceptual expressions of human rights that are modified and transform over the years

2) See Deegan 1990, 2002; Feagin 2001; Feagin, Elias, and Mueller 2009; Hill and Hoecker-Drysdale 2001.

3) See Deegan 1990, 2002; Feagin 2001; Feagin, Elias, and Mueller 2009.

4) See Lyman 1972; McKee 1996; Stanfield 1993, 1985; Steinberg 2007.

5) See Feagin, Elias, and Mueller 2009. 
in response to social changes and historical events. Numerous scholars have noted different stages, layers, and intersections of his political thought and actions. ${ }^{6}$ Over the course of his career, Du Bois embraced multiple human rights political concerns. He theoretically justified and participated in numerous political movements responding to different social contexts and historical circumstances, and he supported the human rights platforms of various oppressed socials groups. Thus, according to different situational contexts, time-periods and geographic spaces, he endorsed integration, socialism, black nationalism, pan-Africanism, and campaigns challenging trans-global oppression of people of color by whites of Western Europe, the United States and other white-led nation-states.

This paper argues that race (whites' misconceptions of race, unequal race relations that favor whites, and widespread abuses of white racism) is a fundamental human rights concern that is best explained by Du Bois. $\mathrm{Du}$ Bois' race-based theoretical explanations of human rights posit a tension between two primary human rights categories: universal human rights and case-specific human rights. These two, diverging, yet interrelated, approaches to discussing human rights present several questions explored throughout the remainder of this paper. First, why did Du Bois feel it necessary to generate theoretical discussions of universal human rights and case-specific human rights, particularly the case-specific human rights of black Americans, blacks outside the United States, and all people of color? Secondly, how did he understand each category of human rights and the relationship among the different human rights perspectives? Finally, what are possible advantages of incorporating Du Bois' multidimensional framework for understanding race-specific human rights as well as universal human rights in local and global contexts; more specifically, how does Du Bois' understanding of the complexity of human rights advance human rights discourse?

\section{Universal Human Rights}

Sociological focus on human rights issues, from earlier days as a graduate student to his final days as an internationally renowned human rights scholar-activist on the frontline, equipped Du Bois with social theoretical insights and language about the rights of all human beings that provide

\footnotetext{
๑) See Dennis 1996; Lewis 1993, 2001; Marable 1986, 1996; Rampersad 1976; Reed 1997.
} 
the foundation for contemporary definitions and declarations of universal human rights (UHR). Du Bois was the first sociologist to develop strong theoretical arguments explaining the sociological importance of human rights for all individuals, groups, nations, and international bodies, specifically universal rights that transcends race, class, gender, and other human divisions. He tirelessly fought for basic human rights of all the exploited, dispossessed, "oppressed and staggering masses" in the US and across the globe, concerned with all of "the unfortunate and the welfare of all the world."7

According to Du Bois, "the slums of London and New York, of Paris and Rome need the exact kind of industrial emancipation that the black people of Africa and the brown people of Asia need... and the question of imperial colonialism is identical with the problem of poverty in Western Europe and America." ${ }^{8}$ He envisioned a "broader humanity" and supported the ideals of "human brotherhood." As Dr. Martin Luther King, Jr. observed, Du Bois "loved progressive humanity in all its hues, black, white, yellow, red and brown... Dr. Du Bois' greatest virtue was his committed empathy with all the oppressed and his divine dissatisfaction with all forms of injustice." ${ }^{10}$

Long before the United Nations' (UN) Universal Declaration of Human Rights' (UDHR) pronouncement of "the inherent dignity and the equal and inalienable rights of all members of the human family" (Preamble from the UN's UDHR), ${ }^{11} \mathrm{Du}$ Bois called for a social world that respects the rights and freedoms of all the "great families of human beings." ${ }^{12}$ Much of the 1948 UN declaration re-presents basic UHR principles that Du Bois identified repeatedly in petitions to the League of Nations and UN and throughout his sociological writings dating back to the late nineteenth century. Judith Blau, President of Sociologists without Borders (sociologists tackling a broad spectrum of human rights issues), echoes the allinclusive "human rights perspective" discovered in Du Bois' sociological writings and life work when she answers the important question, "Why should human rights be important to sociologists?"

7) Du Bois 1970c, pp. 332-33.

8) Du Bois 1982, p. 264.

9) Du Bois 1970a, p. 75; 1995, p. 52.

10) King 1970, p. 18.

11) See "Preamble" to the UN's Declaration of Human Rights on the UN website: http:// www.un.org/Overview/rights.html.

12) Du Bois 1970a, p. 75. 
In a world of exacerbated inequalities, runaway markets, and the merciless disregard of human dignity and security, sociologists will discover that a human rights perspective is useful if they are concerned about social, racial, gender and environmental justice, economic fairness, and equitable nation-states. This perspective holds that all humans are entitled to social, economic, housing, healthcare and political rights; to a cultural, racial, ethnic and sexual identity; and opposes discrimination against minorities and women. It is a subversive perspective, advocating deep forms of democracy and suspicious of capitalism that, by definition, exploits workers. ${ }^{13}$

Throughout his writings and speeches, Du Bois addressed the basic human rights concerns and perspective that Blau outlines. He was mindful and critical of any form of human inequality, opposed the unchecked, highly exploitative market systems of capitalism (national and global), and courageously attacked those who disregard human dignity and security. Addressing multiple human rights concerns in theory and practice, Du Bois generated rich sociological understandings of human rights as well as public sociology concerned with promoting "social, racial, gender and environmental justice, economic fairness, and equitable nation-states." Foreshadowing Blau's list of key human rights concerns, his sociological ideas and practices opposed discrimination and oppression in all forms.

Moreover, as a socialist-leaning critical thinker and actor, he realized that democracy, as a political system, was a far-off ideal and that capitalism remained an unjust, corrupt, exploitative socio-economic system, unless all people possess democratic freedoms and share the fruits of material production. Thus, Du Bois' sociology of human rights promotes "deep" democratic principles best expressed in socialism, anti-racism, and feminism, while criticizing faux or hypocritical forms of democracy tainted by associates with capitalism, racism, and sexism.

While Du Bois believed "all humans are entitled to social, economic, housing, healthcare and political rights," he also recognized that particular human beings (individuals and groups) have case-specific human rights issues directly associated with their "cultural, racial, ethnic and sexual identity." According to Du Bois, human rights are, in reality, reserved for some, but not necessarily extended to all - especially those individuals and groups whose human rights are denied because of their cultural, racial, ethnic, and sexual identity. He writes: "We are willing, and rather glibly, to say that the state is for all but in that all we do not count everybody. We

13) See Judith Blau's "Why should human rights be important to sociologists?" on the Sociologists without Borderswebsite: http://www.sociologistswithoutborders.org/president. html. 
exclude, as the chance may lie, Chinese, or Jews, or Negroes or women... [and yet] no such exclusion can be made without injustice or harm." ${ }^{14}$

Therefore, while he could appreciate the UHR claims of socialist, integrationist and intersectionalist social philosophies, he understood that these ideals rarely manifest in the real world because not all groups experience similar human rights abuses. Each social group experiencing human rights abuses has a distinctive set of human rights issues and specific threat to their basic human rights, social inclusion and societal privileges. For $\mathrm{Du}$ Bois, not all human rights abuses are similar; some group's human rights abuse is greater than others. Among the different groups facing human rights are different degrees of access to institutions, economic and material resources, political and cultural power, and social respect or status. Some groups experience greater oppression, exploitation, and injurious and inhumane treatment than other groups who, nonetheless, experience human rights abuses. Certain oppressed groups suffer more oppression than others according to particular social contexts; moreover, oppressed groups exist within oppressed groups. For example, in "Socialism and the Negro Problem" (1913), Du Bois questions the program of American socialism, which excludes black Americans. He chastises exclusionary socialists, stating: "The essence of social democracy is that there shall be no excluded or exploited classes in the socialistic state; that there shall be no man or woman so poor, ignorant or black as not to count..." 15

His writings indicate the necessity of identifying case-specific human rights for those routinely excluded and denied universal human rights (i.e., black workers who face workplace segregation and discrimination by white workers). Awareness of the contradictions and inconsistencies of so-called universal human rights, which lack universality, prompted Du Bois to create two principal dialogical frameworks for addressing human rights: 1) a UHR theoretical discourse and 2) a theoretical discourse concerning specific human rights cases, particularly cases concerning the human rights of black Americans, all blacks and people of color.

\section{Case-Specific Human Rights}

While he acknowledged and respected case-specific human rights (CSHR) of all oppressed and exploited groups who are denied sanctity under the

14) Du Bois 1985c, p. 102.

15) Du Bois 1970b, pp. 241-42. 
umbrella of universal human rights, Du Bois focused predominantly on the CSHR issues that arise from race, class, and gender inequalities and oppression existing in the social world, often drawing connections binding the three. However, unlike many scholars who discuss the intersectionality of race, class, and gender oppression as co-equal oppressions, without claiming one form of oppression is more widespread and rigid than the others, Du Bois ranks the three oppressions/human rights concerns. Aware that all oppression causes human misery, he nonetheless believes that racial oppression and inequalities create the greatest human misery and social divisions in modern society. According to Du Bois, "the olderst and nastiest form of human oppression [is] race hatred." 16

Thus, among the three, Du Bois prioritized the concerns of oppressed, excluded and exploited racial groups, or race-specific human rights. ${ }^{17}$ Although recognizing the manner in which the social categories of race and class overlap, he did not view the two as synonymous or as interchangeable categories. ${ }^{18}$ For Du Bois, class-based human rights rank behind race-based human rights issues, and, while he viewed gender inequalities and exploitation as central human rights issues with human costs comparable to the others, gender-based human rights ranks third in Du Bois' hierarchy of human rights concerns. ${ }^{19}$ While Du Bois' understanding of a hierarchy of oppression might appear misguided or inappropriate, other scholars have stressed the 'primacy of race' as a social structure and force, documenting how race has largely shaped the modern world. ${ }^{20}$ In Power and Prejudice: The Politics and Diplomacy of Racial Discrimination (1996), Paul Lauren identifies how race has long loomed as the central international human rights issue:

\footnotetext{
16) Du Bois 1999, p. 54.

17) In many ways, Du Bois' focus on race and human rights mirrors Marx's focus on class and human rights, which prioritizes the CSHR issues of class exploitation and oppression, or class-specific human rights. However, while Du Bois recognized the importance of classspecific human rights, Marx failed to recognize the importance of race-specific human rights and social structures.

18) Du Bois discussed the interrelationship between capitalism and racism and, more daringly, identified white elites as the capitalist and racist power brokers who generate profit from economic and racial oppression of poor whites and people of color.

19) At different times, Du Bois would strategically downgrade race-based human rights concerns and prioritize class or gender-based human rights, often in response to heightened class or gender-related human rights abuses associated with specific social-historical contexts.

20) Feagin 2000, 2006; Fredrickson 2002; Goldberg 1993; Lauren 1996; Mills 1997.
} 
The first global attempt to speak for equality focused upon race. The first human rights provisions in the United Nations Charter were placed there because of race. The first international challenge to a country's claim of domestic jurisdiction and exclusive treatment of its own citizens centered upon race. The first binding treaty of human rights concentrated upon race. The international convention with the greatest number of signatories is that on race. Within the United Nations, more resolutions deal with race than with any other subject. And certainly one of the longest standing and frustrating problems in the United Nations is that of race. ${ }^{21}$

Observing the scope, subtleties, and progression of his sociology, one might argue that $\mathrm{Du}$ Bois divides race-specific or race-based human rights (RHR) into three analytic categories: 1) RHR of black Americans = HRBA, 2) RHR of all blacks across the globe = HRAB, and 3) RHR of all people of color $=$ HRCP. In other words, Du Bois draws three primary color lines, racial dividing lines and categories of race-specific human rights inequalities and exclusion. They are the color lines experienced by black Americans, the larger global network of blacks, and broader group of people of color. As his writings demonstrate, Du Bois reacted to these three RHR divisions by developing and implementing three theories and programs of action: Black Nationalism to address HRBA; Pan-Africanism to address HRAB issues; and, anti-colonialism to address HRPC, specifically the trans-global oppression of people of color by Western Europe and the United States.

\section{Human Rights of Black Americans}

Most of Du Bois' early sociology focuses on RHR of black Americans. During his years working at University of the Pennsylvania and Atlanta University, Du Bois conducted in-depth sociological investigations of the black American community in a variety of settings: urban and rural, north and south, as well as black elite, middle-class and working class communities. The Philadelphia Negro: A Social Study (1899), "The Negroes of Farmville, Virginia: A Social Study" (1898), and the "Atlanta University Studies" (1895-1917), sociological research detailing the early twentiethcentury social world of black communities throughout the US, were all concerned with providing information about specific human rights concerns of black Americans. Throughout these works, he notes that black

21) Du Bois 1996, p. 4. 
Americans' human rights are thwarted by a society that promotes whites' human rights and interests at the expense and exclusion of the human rights and interests of black Americans.

In The Philadelphia Negro, Du Bois argues that the advancement of basic human rights in the US is reserved for whites, and that whites largely disregard the livelihood and human rights of black Americans. He writes: "the ancestors of the English, and the Irish and the Italians were felt to be worth educating, helping and guiding because they were men and brothers, while in America a census which gives a slight indication of the utter disappearance of the American Negro from the earth is greeted with illconcealed delight." ${ }^{22} \mathrm{Du}$ Bois explains that black Americans confront a prejudiced, hostile, and unequal social environment of the white world. He notes that social problems confronting blacks result, not only as a result of the group's own social ills ("the Negro Problem"), but also - and more importantly - result because the group is, as a race, highly marginalized, if not excluded, from the ranks of "humanity" and the social environment of "the civilized world" (the white world):

And still this widening of the idea of common Humanity is of slow growth and today but dimly realized. We grant full citizenship in the World Commonwealth to the "Anglo-Saxon" (whatever that may mean), the Teuton and the Latin; then with just a shade of reluctance we extend it to the Celt and Slav. We half deny it to the yellow races of Asia, admit the brown Indians to an ante-room only on the strength of an undeniable past; but with the Negroes of Africa we come to a full stop, and in its heart the civilized world with one accord denies that these come within the pale of nineteenth-century Humanity. ${ }^{23}$

Along with pursuing sociological research that demonstrated human rights abuses and exclusion from humanity of black Americans, Du Bois became politically involved in promoting HRBA outside of the academy. Because of his exclusion from the academy and evolving field of professional sociology and lack of power and resources granted to white sociologists, Du Bois' fight for human rights became more effective after leaving the university and white academic world, a move that marked his shift from a "professional" to "public" sociologist." As a black sociologist in a white-run discipline that was becoming increasingly professionalized and detached

22) Du Bois 1996, p. 387.

23) Du Bois 1996, pp. 386-87. 
from human rights issues, Du Bois' sociological insights were often overlooked and not given the respect and voice they deserved.

Therefore, his most formative sociological activity and voice arose as a public writer and speaker, which presented him a more effective, farreaching forum to announce and poetically agitate against oppression and human rights abuses. Replaced was the muffled voice and constraints of social action that were required while he was a university profession eliciting needed funding for his studies, funding that was tightly controlled by the very oppressors and human rights violators he was attempting to expose.

As he broke free from the constraints of funding-dictated, professional sociology that was largely restricted to presenting uncritical, evasive halftruths about society and power abuses in the social world, Du Bois effectively used words and actions to politically challenge (race-class-gender) oppressors' systems and beliefs and advance human rights concerns of the oppressed. Throughout the first half of the century, in addition to editing the NAACP's important journal, The Crisis, he organized and helped organize numerous political battles against oppression and campaigns for human rights. He was behind the formation of the Niagara Conference and Movement, a 'nationalist' 'local' social movement of black Americans struggling for human rights, to Pan-African Conferences and Congresses, 'international,' 'global' social movements of all blacks struggling for human rights. The early civil rights movement of US blacks and trans-global PanAfrican civil rights movement of all blacks spoke directly to white oppression in the US and European-dominated colonies in Africa, the Americas, and other colonized territories. Leading the charge with petitions and declarations to state and federal US government officials as well as officials of international political bodies like the League of Nations and UN, Du Bois boldly challenged white politicians and power brokers of white-controlled nations to address their social misdeeds, specifically their human rights abuses of US blacks and blacks worldwide.

In 1905, the Niagara Movement was born when Du Bois joined forces with other politically progressive, social reformist black Americans who coalesced to address HRBA issues. The group presented their "Declaration of Principles," a summary of HRBA concerns, in a leaflet author by $\mathrm{Du}$ Bois. In this human rights declaration, he outlines a specific set of human rights concerns for "Negro-Americans." Yet, before addressing specific human rights concerns of black Americans, Du Bois humanizes US blacks by first acknowledging the culture, talents, worth, and strides of the individuals and groups of the black American community. The pam- 
phlet begins: the "members of the conference" observe black Americans' "certain undoubted evidences of progress... particularly the increase of intelligence... and the demonstration of constructive and executive ability in the conduct of great religions, economic and educational institutions." ${ }^{24}$ After establishing the human-ness or humanity of the black American community, Du Bois specifies the human rights concerns of black Americans.

We believe that this class of American citizens [black Americans] should protest emphatically and continually against curtailment of their political rights ["Suffrage"] ... protest against the curtailment of our civil rights ["Civil Liberty"] ... [and] complain against the denial of equal opportunities to us in economic life ["Economic Opportunity"]. ${ }^{25}$

The remainder of the pamphlet addresses other HRBA concerns, such as education, the justice system, media representations that fuel public opinion, health, unionization, social protest/agitation, racial discrimination, oppression, and segregation of the color line. Du Bois later addressed all of the above HRBA issues in the pages of journals, like The Horizon: A Journal of the Color Line (Horizons) and The Crisis, and throughout his other sociological writings. He never discarded or diminished HRBA issues, even as he embraced human rights issues of all blacks, people of color, and oppressed whites. HRBA was Du Bois' home ground, his starting point the human rights issues he knew best. What is more, as a black American desiring a better world for himself and other black Americans, Du Bois felt a certain obligation and calling to HRBA.

Yet, early in his sociological writings, Du Bois occasionally discussed the importance of RHR on two other levels, the human rights of all blacks (HRAB) and human rights of all people of color (HRPC). He viewed black Americans as part of a larger group of blacks, who, in turn, are part of a larger group of people of color, like browns (Indians, Middle Easterners, and Pacific Islanders), reds (Native Americans), and yellows (Asians), a crude but utilized color-coded breakdown of 'races.' While, for Du Bois, each group - black Americans, all blacks, and people of color - is distinctive, not being reducible to the others, the three are deeply connected by the fact that they all experience the 'problems' of the color line (racial segregation and oppression) created by whites.

\footnotetext{
24) Du Bois 1986a, p. 55.
}

25) Du Bois 1986a, p. 55. 


\section{Human Rights of All Blacks}

While Du Bois used terms like the "American Negro" and "black American" to specify US blacks, he also occasionally referred to black Americans as "blacks" or "Negroes," without any reference to America. Thus, at times, he spoke of blacks as a "vast historic race" of all Africans and, at other times, spoke of blacks specifically in reference to black Americans. As he traveled internationally and became more involved with the Pan-Africanist movement, Du Bois increasingly viewed the experiences of black Americans and all people of sub-Saharan African descent as "Negroes" or blacks, while recognizing that each group has particular sets of social, economic, political, and cultural issues related to their different homelands.

In a 1909 edition of Horizons, ${ }^{26}$ Du Bois announced the journal's "policy," stating: "This is a radical paper. It stands for progress and advance. It advocates Negro equality and human equality." ${ }^{27}$ What was behind Du Bois' policy to divide "Negro equality" (case-specific human rights) and "human equality" (universal human rights)? Recounting human rights issues and concerns discussed at the 1909 National Negro Conference and Fifth Annual Address of the Niagara Movement, he provides possible answers to this question.

Hitherto there has been in this country a strange, to some, almost inexplicable hiatus between the cause of Negro uplift and other great causes of human advance. If one met the workers for women's rights, prison reform, improvement in housing, consumer's leagues, social settlements, universal peace, socialism, almost any of the myriad causes for which thinkers and doers are today toiling, one met persons who usually either knew nothing of the Negro problem or avoided it if they did know. ${ }^{28}$

Du Bois observed a disconnect between "the cause of Negro uplift and other great causes of human advance," indicating that "the myriad causes

\footnotetext{
26) Du Bois addressed human rights issues as the editor of Moon (1905-1907) and The Horizon: A Journal of the Color Line (1907-1910) before becoming editor of The Crisis (1910-1934), the popular and influential journal of the National Association for the Advancement of Colored People (NAACP). Du Bois used these journals, along with his many other writings and communications, as a method of publicizing human rights abuses of blacks and immoral treatment of all oppressed peoples. See Herbert Aptheker's Introduction to Writings in Periodicals Edited by W.E.B. Du Bois: Selections from The Horizon (1985).

27) Du Bois 1985b, p. 80 .

28) Du Bois 1985b, p. 80.
} 
for which thinkers and doers are today toiling" - under the name of universal human rights - excludes or overlooks the human rights of blacks. According to Du Bois, "women's rights" (gender issues) and "socialism" (class issues) are recognized categories of the human rights dialogue, while the Negro problem (the issue of race) is thoroughly neglected. Because race-based human rights issues were routinely overlooked in the US and international politics, Du Bois likely deemed it necessary to maintain a separate category that specifically acknowledged the unaddressed, at times, purposefully concealed, race-based human rights issues facing blacks.

Additionally, it would appear that Du Bois endorsed a separate human rights category for blacks because he witnessed that blacks have suffered the greatest human rights abuses through the global slave system, viewing these abuses as extraordinary cases. He also realized that blacks require their own human rights platform because the human rights concerns of whites - a whites-only human rights agenda - inevitably bypass and overshadow/drown out human rights concerns of blacks. Even worse, whites, adopting the role of the society-defined superodinate and leader of civilization, culture, and intelligence, often attempt to authoritatively voice and dictate the human rights concerns of blacks. While at times whites act out of a misguided paternalistic sincerity, in most cases whites' attempt to control human rights concerns of blacks involves whites' efforts to maintain black subordination. According to Du Bois, a universal human rights agenda is incomplete and problematic as long as it ignores or scorns the case-specific human rights of blacks. More to the point, a whites-only human rights agenda is not a "universal" human rights agenda. Instead, whites-only human rights demonstrate an obvious hypocrisy of human rights, generating a need for all blacks to oppose white systems of exploitation, inequalities, and oppression, to challenge the "lynching of emancipation" by "allied peoples who have yelled about democracy and never practiced it." 29

Du Bois was aware that many white political leaders who preach democracy and human rights usually are referring to democracy and human rights for whites. Walter White of the NAACP and Eleanor Roosevelt are examples of whites often associated with the advancement of human rights, particularly through their interactions as US representatives with the Human Rights Commission of the UN. However, in numerous historical

29) Du Bois 1967 , p. 332. 
analyses and in biographical and autobiographical writings on Du Bois, it becomes clear that White and Roosevelt, for both similar and different reasons, blocked Du Bois' call for addressing the human rights of blacks. They were reluctant about presenting the thorny issue of RHR, considering the US government and American society staunchly supported the Jim Crow social system responsible for everyday RHR violations against black Americans. ${ }^{30}$ Through these unsettling experiences with 'more sympathetic,' 'liberal' whites oblivious to rights abuses of white racism, Du Bois realized that the human rights concerns of blacks, in the US and abroad, could not be entrusted to white political leaders, who knowingly or unknowingly "have historical strong interest in preserving their present power and income" that rests on white racism.

Because of whites' stake in maintaining racial power, which requires the subjugation of blacks, Du Bois advocated that black leaders are necessary actors for securing blacks' human rights. Subsequently, he argued for creation of a "Talented Tenth" - social, political, cultural, and intellectual leaders within the black community - to identify the central human rights concerns of blacks, specifically the most destructive mechanisms of white oppression, and develop programs of action to address those concerns and other important matters within the black community. According to $\mathrm{Du}$ Bois, black leaders would guide the struggle for human rights, both HRBA and HRAB; it would be "their knowledge of modern culture [that] could guide the American Negro into a higher civilization.” Without black leaders, "the Negro would have to accept white leadership, and that such leadership could not always be trusted to guide this group into self-realization and to its highest cultural possibilities." 31

As more examples of the abuses and range of white power dramatically emerged during the first half of twentieth century, Du Bois realized that whites wished to extend and exert colonial power - a totalitarian white empire - over all people of color across the globe. He thus theorized that, while devastation of black civilization and culture was an exceptionally brutal because of the global slave trade and chattel slavery that early enriched Europe and white America, modern-day imperialism of white colonialist powers disregards the human rights of blacks and all people of color.

30) See Anderson 2003; Du Bois 1967; Lewis 2000; Lauren 1996.

31) Du Bois 1967, p. 236. 
Not only does Western Europe believe that most of the rest of the world is biologically different, but it believes that in this difference lies congenital inferiority; that the black, brown and yellow people are not simply untrained in certain ways of doing and methods of civilization; that they are naturally inferior and inefficient; that they are a danger to civilization, as civilization is understood in Europe. ${ }^{32}$

According to Du Bois, "modern lust for land and slaves in Africa, Asia, and the South Seas" by "so-called civilized peoples" was the fuel for " "colonial' aggression and 'imperial' expansion." "33 With this knowledge of whites' attempt to dominate nonwhite territories and resources (including the people) across the globe, $\mathrm{Du}$ Bois worked to forge and develop relations political, intellectual, economic, educational, cultural, and even military ties - with social and political leaders of black Americans, all blacks, and people of color who would oppose white imperialist domination and colonization.

\section{Human Rights of People of Color}

Du Bois realized that, because of their economic deprivation and lack of modern industry and technologies, blacks should join forces with other people of color to combat white imperialism. According to Elliot Rudwick, "Du Bois accomplished so little in trying to unite Negroes of various nations, [thus] in 1930 he spoke about the possibility of American Negroes joining China, India, Egypt, and Ethiopia in a 'world movement of freedom for colored races. ' "34 Rudwick points out that, despite repeated attempts, Du Bois was unable to forge alliances among blacks or among blacks and people of color. He increasingly realized that it was unlikely that the "'dark world' (Japan, China, India, Egypt, and the Negroes of the United States, the West Indies, and West Africa) would wage war against the 'white world." While Du Bois' vision of unifying "black, [red], brown, and yellow peoples" might not exhibit the wide-ranging interracial community that Du Bois (or Rudwick) had desired, through his ideas and efforts to unite people of color to challenge whites' abuse of power, however, we are today able to witness partial and selective unity among people of color on different fronts. Asian, African, South American and

32) Du Bois 1944, p. 22.

33) Du Bois 1967, p. 348.

34) Du Bois 1982, p. 234. 
Island nations have bonded on some levels (normally according to region), forming alliances to offset Western imperialism of whites.

White colonization of people of color continues to this day, over a half of a century after Du Bois called attention to the human rights of all people of color under white colonial rule. One of his most powerful critiques against white colonization was his criticism of the International Bill of Rights presented at the 1945 UN conference in San Francisco, a vague statement about human rights "without any specific mention of... the 750 million people who live in colonial areas." 35 Writing about the effects of colonization on people of color perpetrated by white economic, political, and military powers, Du Bois paints a disturbing portrait of the colonized people of color under white imperialism:

The most depressed peoples in the world... who hitherto for the most part have been considered as sources of profit and not included in the democratic development of the world... whose exploitation for three centuries has been the prime cause of war, turmoil, and suffering... omission of specific reference to these peoples is almost advertisement of their tacit exclusion as not citizens of free states, and that their welfare and freedom would be considered only at the will of the countries owning them..." 36

Although he focused on the general lack of awareness or concern toward human rights of all people of color, Du Bois did not view race-based human rights issues of people of color in isolation from other human rights problems. Moreover, he did not believe that race-based human rights issues should be the only focus of people of color. Especially with his move toward socialism and appreciation of the socio-political ideologies and economic idealism of the Soviet Union (a white nation) in his later life, $\mathrm{Du}$ Bois found that human rights problems of people of color, while distinctive, are interconnected to other groups' human rights issues, even those of oppressed whites. Yet, he understood that "the attempt to submerge the colored races is one of the world-old efforts," making emancipation of people of color a singular important issue. At the same time, he also knew that emancipation of people of color was interwoven and necessarily related with other primary forms of emancipation, gender and class emancipation, and that to ignore or step on other human groups' oppression and fight for emancipation is to jeopardize one's own primary group oppression and emancipation.

35) Du Bois 1967, p. 348.

36) Du Bois 1967 , p. 348. 


\section{Conclusion - Du Bois' Color-Coded Web of Human Rights Concerns}

$\mathrm{Du}$ Bois developed a complex theoretical understanding of human rights that reflects the complex human rights issues facing human beings throughout the twentieth century and into the dawn of the twenty-first century. Early in his work, he recognized universal human rights concerns in the links between the oppression of poor white workers and blacks, but focused on the plight of blacks because, no matter how poor, white workers possessed the benefits of white racial privileges (social status, political power, access to better jobs, housing, education, social freedoms and 'basic' human rights). As his sociological worldview expanded, Du Bois hoped that blacks could "make common cause with the oppressed and down-trodden of all races and peoples; with our kindred in South Africa and West Indies; with our fellow in Mexico, India and Russia and with the cause of working classes everywhere." ${ }^{37}$ In 1946, he would again repeat the same message, proclaiming that black Americans should strive "not simply for emancipation of the American Negro but for the emancipation of the African Negro and Negroes of the West Indies; for emancipation of the colored races; and for the emancipations the white slaves of modern capitalistic monopoly." ${ }^{38}$

Despite his strong ties with socialism and "realization of that broader humanity which freely recognizes differences in men [human beings], but sternly deprecates inequality in their opportunities of development," Du Bois recognized that UHR is not enough, that the contemporary social world stills needs to seriously address RHR. ${ }^{39}$ While cogent of less-powerful whites who suffer human rights abuses, he held that the greatest human rights abuses are race-based human rights abuses that target blacks and people of color, thus a RHR platform was necessary. For Du Bois, RHR are divided into three subcategories of human rights concerns associated with three principal social groups: HRBA; HRAB; and, HRCP. Thus he reasoned that, while united against white oppression, each group possessed their own particular set of human rights issues related to political, socioeconomic, cultural-intellectual and regional differences. It is the duty of each racially oppressed group to fight their own specific local battle, as well as the larger global war, against white racial imperialism.

\footnotetext{
37) Du Bois 1985b, p. 84

38) Du Bois 1967, p. 332.

39) Du Bois 1970 a, p. 81.
} 
Although most of his writings focus on human violations against black Americans, blacks and other people of color, Du Bois routinely and tactfully shifts sociological investigations away from human rights abuses against people of color and toward the dominant human rights of whites. Du Bois (1920, 1940, 1945, 1946) delivers harsh criticisms of whites' human rights violations of people of color. By shifting focus away from people of color's subjugation to acts of white oppression, Du Bois exposed a highly concealed social truth about whites' role in stifling human rights of people of color, a realization many contemporary sociologists ignore.

$\mathrm{Du}$ Bois' understanding of human rights denotes a conceptual split between UHR and CSHR, specifically RHR, is a necessary theoretical distinction that is relevant for today's social thinkers who wish to comprehend the history and dynamics of human rights. RHR are a necessary theoretical framework for contending with the persistence of ideologies of white superiority/inferiority of people of color, white-controlled social systems of power targeting human rights of all people of color, and people of color's second-class political status and denial of basic human rights. Until this social condition is remedied, Du Bois' model of the relationship between UHR and RHR, as well as his breakdown of HRBA, HRAB, and HRCP, provide essential concepts and theoretical understandings for a more nuanced sociological discourse of human rights, one that demonstrates that the anti-racism human rights project is as urgent today as during Du Bois' lifetime. ${ }^{40}$

According to $\mathrm{Du}$ Bois, if a universal human rights agenda is to be truly universal, it must embrace a race-specific human rights agenda of blacks and people of color, just as it must embrace CSHR of women, the poor, and other oppressed, marginalized social groups. While human rights play a central role in "today's global order," human rights in a global context are directly linked with human rights at various localities and among different positionalities. The plurality of human rights concerns reaches

\footnotetext{
40) Prefiguring the 1965 UN resolution, "Elimination of All Forms of Racial Discrimination," Du Bois' very last writings, like his earliest, discussed the need to balance RHR and UHR. In "A Petition to the Honorable John F. Kennedy" (1961), composed just before his death, Du Bois called on President Kennedy to use his political power to address the persistence of race-specific human rights abuses: "Mr. President, order an end to discriminatory practices based on race, nationality, creed or color in the realm of employment and job tenure, voting, housing and education... democracy must embrace all or it will embrace none" (1985d, pp. 318-9).
} 
beyond the dichotomy and debates between national (citizenship) and international human rights prevalent in much HR discourse. Du Bois' understanding of RHR (along with class-based and gender-based human rights) are distinct from 'national' (or 'citizenship') or 'international' human rights concerns, and are not subsumed under or regulated to the categories of national/citizenship or international human rights concerns. ${ }^{41}$

Human rights advocates might heed Du Bois' model of race-based human rights concerns as a critique of unidimensional international/global and national/local human rights concerns that are color-blind and overlook case-specific human rights concerns.

\section{Bibliography}

Aptheker, Herbert 1985, Introduction, in Herbert Aptheker (ed.), Writings in Periodicals Edited by W.E.B. Du Bois: Selections from The Horizon, White Plains, NY: KrausThomson Organization.

Anderson, Carol 2003, Eyes Off the Prize: The United Nations and the African American Struggle for Human Rights, 1944-1955, Cambridge: Cambridge University Press

Blau, Judith 2008, 'Why should human rights be important to sociologists?', http://www. sociologistswithoutborders.org/president.html.

Deegan, Mary J. 2002, Race, Hull-House, and the University of Chicago: A New Conscious Against Evil, Westport, CT: Praeger.

Deegan, Mary J. 1990 [1988], Jane Addams and the Men of the Chicago School, 1892-1918, New Brunswick, NJ: Transaction Books.

Dennis, Rutledge M. 1996, 'Continuities and Discontinuities in the Social and Political Thought of W.E.B. Du Bois', in Rutledge M. Dennis (ed.), Research in Race and Ethnic Relations: W.E.B. Du Bois: The Scholar as Activist, Volume IX: 3-23, Greenwich, CT: JAI Press Inc.

Du Bois, W.E.B. 1898, 'The Negroes of Farmville, Virginia: A Social Study', The Bulletin of the Department of Labor, 14 (January).

Du Bois, W.E.B. 1944, 'Prospect of a World without Racial Conflict,' American Journal of Sociology, 49 (March): 450-56.

Du Bois, W.E.B. 1970a [1897], 'The Conservation of the Races', in Philip Foner (ed.), WEB Du Bois Speaks: Speeches and Addresses, 1920-1963, New York: Pathfinder Press.

Du Bois, W.E.B. 1970b [1913], 'Socialism and the Negro Problem', in Philip Foner (ed.), WEB Du Bois Speaks: Speeches and Addresses, 1920-1963, New York: Pathfinder Press.

41) See Turner 1993; Sjoberg, Gill, and Williams 2001; Hafner-Burton and Tsutsui 2005. 
Du Bois, W.E.B. 1970c [1958], 'The Negro and Socialism', in Philip Foner (ed.), WEB Du Bois Speaks: Speeches and Addresses, 1920-1963, New York: Pathfinder Press.

Du Bois, W.E.B. 1982 [1947], 'A Program of Emancipation for Colonial Peoples', in Herbert Aptheker (ed.), Writings by W.E.B. Du Bois in Non-Periodical Literature Edited by Others, Millwood, New York: Kraus-Thomson.

Du Bois, W.E.B. 1985a [1900 ?], 'The Spirit of Modern Europe', in Herbert Aptheker (ed.), Against Racism: Unpublished Essays, Papers, Addresses, 1887-1961, Amherst, MA: The University of Massachusetts Press.

Du Bois, W.E.B. 1985b [1909], 'Our Policy' and 'National Negro Conference', in Herbert Aptheker (ed.), Writings in Periodicals Edited by W.E.B. Du Bois: Selections from The Horizon, White Plains, NY: Kraus-Thomson.

Du Bois, W.E.B. 1985c [1910], 'The Temptation', in Herbert Aptheker (ed.), Writings in Periodicals Edited by W.E.B. Du Bois: Selections from The Horizon, White Plains, NY: Kraus-Thomson.

Du Bois, W.E.B. 1985d [1961], 'A Petition to the Honorable John F. Kennedy', in Herbert Aptheker (ed.), Against Racism: Unpublished Essays, Papers, Addresses, 1887-1961, Amherst, MA: The University of Massachusetts Press.

Du Bois, W.E.B. 1986a [1905], 'The Niagara Movement: Declaration of Principles', in Herbert Aptheker (ed.), Pamphlets and Leaflets by W.E.B. Du Bois, White Plains, NY: Kraus-Thomson.

Du Bois, W.E.B. 1986b [1940], Dusk of Dawn: An Essay Toward an Autobiography of a Race Concept, in Nathan Huggins (ed.), in W.E.B. Du Bois Writings: The Suppression of the African Slave Trade, The Souls of Black Folk, Dusk of Dawn, Essays and Articles, New York: Penguin.

Du Bois, W.E.B. 1990 [1945], Color and Democracy: Colonies and Peace, Millwood, NY: Kraus-Thomson.

Du Bois, W.E.B. 1995 [1903], The Souls of Black Folk, New York: Penguin Books.

Du Bois, W.E.B. 1996a [1899], The Philadelphia Negro: A Social Study, Philadelphia: The University of Pennsylvania Press.

Du Bois, W.E.B. 1996b [1946], The World and Africa: An Inquiry Into the Part Which Africa Has Played in World History, New York: International Publishers.

Du Bois, W.E.B. 1997 [1968], The Autobiography of W.E.B. Du Bois: A Soliloquy on Viewing My Life from the Last Decade of Its First Century, New York: International Publishers.

Du Bois, W.E.B. 1999 [1920], Darkwater: Voice From Within the Veil, Mineola, NY: Dover Publications.

Du Bois, W.E.B. 2008 [1896-1947], 'Atlanta University Studies', WEB DuBois.org, http://www.webdubois.org/wdb-AtlUniv.html.

Feagin, Joe R. 2000, Racist America: Roots, Current Realities, and Future Reparations, New York: Routledge.

Feagin, Joe R. 2001, "Social Justice and Sociology: Agendas for the Twenty-First Century", American Sociological Review, 66:1-22.

Feagin, Joe R. 2006, Systemic Racism: A Theory of Oppression, New York: Routledge.

Feagin Joe R. and Hernán Vera 2008 [2001], Liberation Sociology, Second Edition, Boulder, O: Paradigm Publishers. 
Feagin, Joe R., Sean Elias, and Jennifer Mueller 2009, 'Social Justice and Critical Public Sociology', in Vincent Jeffries (ed.), Handbook of Public Sociology: Toward a Holistic Sociology, Lanham, MD: Roman and Littlefield.

Fredrickson, George 2002, Racism: A Short History, Princeton, NJ: Princeton UniversityPress.

Goldberg, David 1993, Racist Culture: Philosophy and the Politics of Meaning, Oxford: Blackwell.

Hafner-Burton, Emilie and Kiyoteru Tsutsui 2005, 'Human Rights in a Globalizing World: The Paradox of Empty Promises', American Journal of Sociology, 110(5):1373-411.

Hill, Michael R. and Susan Hoecker-Drysdale (eds.) 2001, Harriet Martineau: Theoretical and Methodological Perspectives, New York: Routledge.

King, Jr., Martin. L. 1970 [1968], 'Honoring Dr. Du Bois', in Philip Foner (ed.), WEB Du Bois Speaks: Speeches and Addresses, 1920-1963, New York: Pathfinder Press.

Lauren, Paul G. 1996 [1988], Power and Prejudice: The Politics and Diplomacy of Racial Discrimination, Boulder, CO: Westview Press.

Lewis, David L. 1993, W.E.B. Du Bois: Biography of a Race (1869-1919), New York: Henry Holt.

Lewis, David L. 2001, W. E. B. Du Bois, 1919-1963: The Fight for Equality and the American Century, New York: Henry Holt.

Lyman, Stanford 1972, The Black American in Sociological Thought, New York: G.P. Putnam and Sons.

Marable, Manning 1986, W.E.B. Du Bois: Black Radical Democrat, New York: Twayne Publishers.

Marable, Manning 1996, 'The Pan-Africanism of W.E.B. Du Bois', in Bernard Bell, Emily Grosholz, and James B. Stewart (eds.), W.E.B. Du Bois on Race and Culture, New York: Routledge.

McKee James 1993, Sociology and the Race Problem: The Failure of a Perspective, Urbana, IL: University of Illinois Press.

Mills, Charles 1997, The Racial Contract, Ithaca, NY: Cornell University Press.

Rampersad, Arnold 1976, The Art and Imagination of W.E.B. Du Bois, Cambridge, MA: Harvard University Press.

Reed, Jr., Adolph 1997, W.E.B. Du Bois and American Political Thought: Fabianism and the Color Line, New York: Oxford University Press.

Rudwick, Elliott 1982 [1960], W.E.B. Du Bois: Voice of the Black Protest Movement, Urbana, IL: The University of Illinois Press.

Sjoberg, Gideon, Elizabeth A. Gill, and Norma Williams 2001, 'A Sociology of Human Rights', Social Forces, 48(1):11-47.

Stanfield, John H. 1985, Philanthropy and Jim Crow in American Social Science, Westport, CT: Greenwood Press.

Stanfield, John H. 1993, Introduction, in John H. Stanfield (ed.), A History of Race Relations Research: First Generation Recollections, Newberry Park, CA: Sage Publications.

Steinberg, Stephen 2007, Race Relations: A Critique, Stanford, CA: Stanford University Press.

Turner, Bryan S. 1993, 'Outline of a Theory of Human Rights', Sociology, 27(3):489-511

United Nations 2008 [1945], 'Preamble', Declaration of Human Rights, United Nations' Website, http://www.un.org/Overview/rights.html. 
United Nations 2006 [1965], General Assembly Resolution 2106 (XX) of 21 December 1965, International Convention on the Elimination of All Forms of Racial Discrimination, Office for the High Commissioner of Human Rights' Website, http://www. unhchr.ch/html/menu3/b/d_icerd.htm. 
Copyright of Societies Without Borders is the property of Brill Academic Publishers and its content may not be copied or emailed to multiple sites or posted to a listserv without the copyright holder's express written permission. However, users may print, download, or email articles for individual use. 